枝松秀雄1)，渡辺健介1)，喜友名朝盛1)，利波久雄2)

1) 獨協医大越谷病院耳鼻科 2) 金沢医大放射楾科

（目的）内耳の複雑な立体構造を3次元的な画像としてとらえるために、骨迷路に対しては 3 次元CTを、膜迷路 には 3 次元MRI 撮影を行い、内耳の鮮明な立体画像が観察可能となったので報告する。

(方法と対象) CT (TCT-900S) は. $1 \mathrm{~mm}$ 間隔でのラセン撮影後に3次元画像を作成した。MRI (1.5 Tesla のMagnetom Vision)では、最近開発された3D-CISS法を用いて、乾燥骨と正常耳10耳で撮影した。

（結果とまとめ）乾燥側頭骨と正常内耳での 3 次元 C T とMRI では、従来の 2 次元的な画像では困難であった蝸 牛、三半規管, 前庭、第 8 神経などの複雑な解剖像が、観察角度の跱節により同一画面内に 3 次元的な立体像とし て任意の方向から明瞭に観察可能となった。今回の3 次元画像では、内耳の立体的な解剖の確認は容易である が、内耳内の病態診断への有用性については、今後多くの症例の病態と画像所見を慎重に娭討する必要がある。

330 神経血管王迫症候群としてのめまい症例とMRI 像

\author{
中學战人 \\ 日赤艮崎原爆捖院耳咽喉料
}

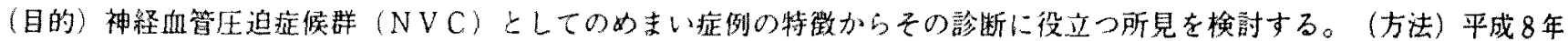
4 月から平成 9 年 8 月までの問にNVCによるかまいと診断した16例（8.5\%）の庭状、検查所見につき検討した。（結果） 12 例が回転性めまいを訴え、8例がリー5時間の持統で、めまい発作が治まると全例ではは即座に正常となった。娭査では

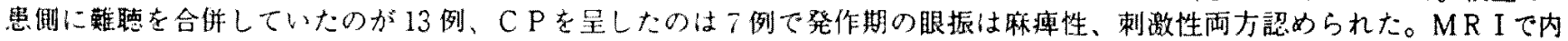

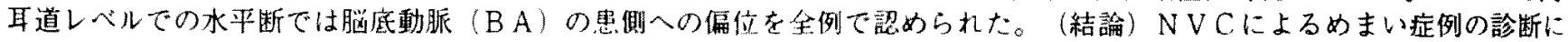
はMRIの内耳道しベルでの水平断におけるBAの偏位が役立つ上思われた。

\title{
331 めい診断におけるMRI怏查の役制
}

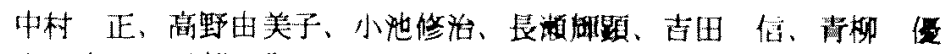
山形大学医学部耳基因訟科

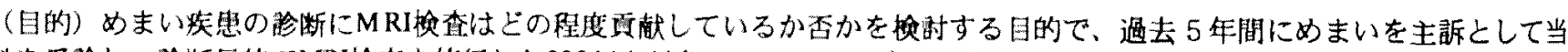

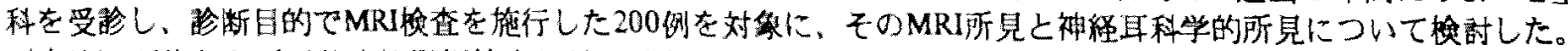

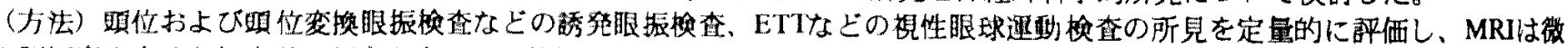

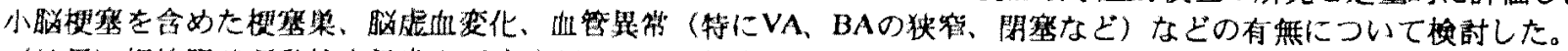

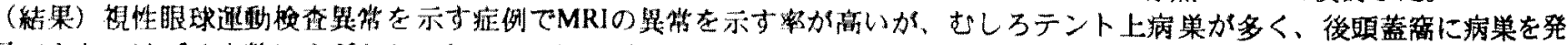
見できたのはごく少数にすきなかった。他の所見においてはMRIの異敌出現率には全く差がなかった。

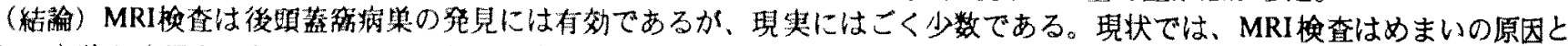
なる病果を磪認するというよりも、むしる大多数の症例では脳の虚血状態の評価にその意義があると結論した。

332高䠲者のめまい症における椎骨脳底動脈系のMRA一特に前下小脳動脈、後下小脳動脈の描出一

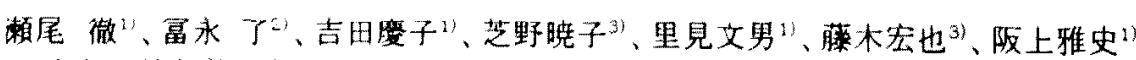

1)兵庫医科大学耳咽喉科、2)同放射線科、3)宝塚市立病院耳咽唯科

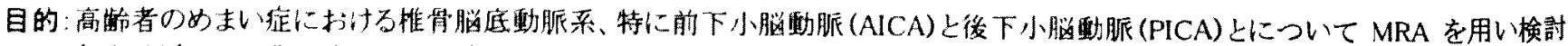

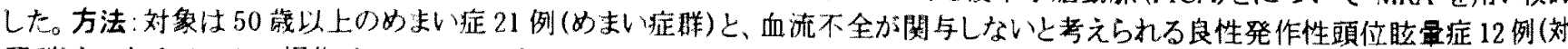

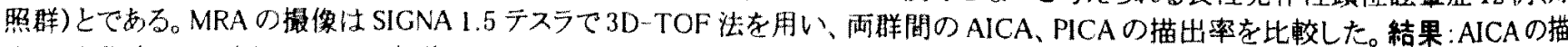

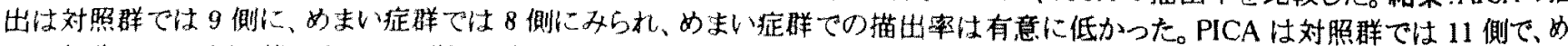

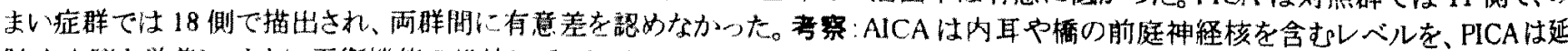

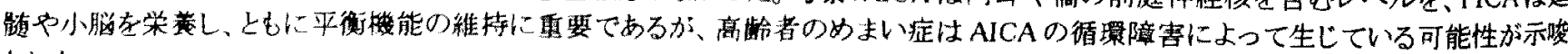
された。 